\title{
Recurrent wheezy bronchitis and viral respiratory infections
}

\author{
J Mertsola, T Ziegler, O Ruuskanen, T Vanto, A Koivikko, P Halonen
}

\begin{abstract}
Fifty four patients aged from 1 to 6 years who had had recurrent attacks of wheezy bronchitis were prospectively followed up for three months to find out if there was an association between different viral respiratory infections and episodes of wheezing. Of the $\mathbf{1 1 5}$ episodes of upper or lower respiratory tract symptoms, virus or Mycoplasma pneumoniae infections were diagnosed in $52(45 \%)$. Thirty four of these $(65 \%)$ were caused by coronaviruses or rhinoviruses. The patients had an average of $2 \cdot 1$ episodes of respiratory tract symptoms the total mean (SD) duration of which was 30 (2) days of the 92 days that followed. Wheezing occurred during $76(66 \%)$ of the 115 episodes and during a third of these the patient was admitted to hospital because of severe dyspnoea. Wheezing started a mean (SD) of 43 (7) hours after the first symptoms of respiratory infection and persisted for $3.8(4.2)$ days in patients in whom virus infection was diagnosed. The incidence of wheezing was not associated with IgE mediated atopy, with positive virological tests, or with fever during virus infection, but was associated with parental smoking and more than one sibling.
\end{abstract}

Wheezy bronchitis, also called asthmatic bronchitis, is an acute recurrent respiratory illness characterised by cough, rhonchi, and expiratory distress in young children with hyper-reactive airway disease. ${ }^{1}$ Viral infections play a large part in exacerbations of wheezing attacks in these children, ${ }^{2-4}$ but the mechanisms of virus induced airway obstruction are complex and only partially understood. ${ }^{5-7}$ There is some epidemiological evidence that wheezy bronchitis represents a definite subdivision of wheezing disease. ${ }^{8}$ Several authors, however, regard wheezy bronchitis and asthma as the same disorder, because these two diseases share common clinical signs and possible similarities in pathogenesis. ${ }^{9-11}$

Although the treatment of wheezy bronchitis usually follows the same regimen as bronchial asthma, some young patients do not seem to benefit from treatment with sympathomimetics. ${ }^{12}$ Particularly controversial is the optimal treatment of a young child with recurrent wheezing who requires daily medication. ${ }^{13}$

This prospective study was conducted to obtain baseline information about the natural course of wheezy bronchitis and the role of different viral infections in children prone to recurrent attacks of wheezy bronchitis.

\section{Patients and methods}

Children aged from 1 to 6 years who had attended the Department of Paediatrics, Turku University Hospital between September 1985 and August 1986 and who had had two or more attacks of wheezy bronchitis with one or more admission to hospital were invited to participate in the study. To ensure adequate cooperation in follow up, only children who lived within $50 \mathrm{~km}$ of the hospital were considered. These criteria were fulfilled by 62 children.

Fifty six of the children participated at the prestudy visit in September 1986. The parents were informed about the nature and requirements of the study and informed consent was obtained. A medical history was taken, and questions were asked about aspects of each child's environment. A physical examination was done, and a venous blood sample taken.

The parents of two patients did not contact us despite the fact that their children had repeated infections during the follow up period. These children were excluded and the study group therefore consisted of 54 children. The mean age of the patients was $3 \cdot 2$ years (range $1-6$ ) and 40 of them $(74 \%)$ were boys. Eighteen patients were being treated by daily inhalations (either beclomethasone or sodium cromoglycate), three of them were having additional theophylline, and three were taking theophylline alone.

The parents were asked to bring their child to the hospital emergency room within 48 hours if their child developed signs and symptoms of an acute respiratory infection, wheezing or dyspnoea during the three month follow up period from October to December 1986. During this visit a physical examination was made by one of us $(\mathrm{JM})$ and a specimen of nasopharyngeal secretion was taken. Patients who wheezed were treated with oral or inhaled salbutamol, and those with more severe dyspnoea were treated in the emergency room with nebulised salbutamol. Patients with severe dyspnoea who failed to respond to the nebulised drug were admitted to hospital.

Parents recorded the symptoms of the child daily on a personal symptom card during the whole three month period. Two weeks after the examination that had taken place during the acute attack the patients were examined again, a venous blood sample for viral serology was taken, and the symptom card was checked. A new episode of respiratory infection or wheezing was considered to have occurred when the symptoms of the previous episode had disappeared at least seven days before the new one started.

In January 1987 all the children were evalu- 
ated again (post-study physical examination) and a venous blood sample was taken for viral serology.

The control group was taken from 112 sex and age matched controls selected from the official register of the general population in the Turku area; they had been asked to fill in a questionnaire about their medical history, environment, and development of respiratory symptoms during the year before the prospective study was carried out. Parents from 69 children $(62 \%)$ responded. Fifty four of the controls $(78 \%)$ were boys and the mean age of the group was $3 \cdot 3$ years. Control children were not followed up in the same way as the study group, but were included to compare the history of respiratory infections and wheezing in a random group of children of similar age.

\section{RISK FACTORS}

For retrospective analysis of the association between environmental factors and the predisposition of the children to wheeze, the study group and their controls were divided into groups according to the type of day care they received, exposure to cigarette smoke, and number of siblings. The symptoms of allergy, numbers of respiratory infections and courses of antibiotics during the preceding year were also recorded.

\section{VIROLOGICAL STUDIES}

Samples of nasopharyngeal mucus were collected by aspiration of secretions from the nasopharynx through the nostrils with a disposable mucus extractor (Vycon). For isolation of viruses a cotton stick was dipped into the samples of mucus and then placed into a phial containing $2 \mathrm{ml}$ virus transport medium $(0.5 \%$ bovine albumin in tryptose phosphate broth containing antibiotics). The phials were kept for less than two hours in iced water and transported to the laboratory, where they were stored at $-70^{\circ} \mathrm{C}$ until assayed.

The specimens for isolation of viral antigens were kept at $4^{\circ} \mathrm{C}$ until studied. The mucus was diluted 1:5 in phosphate buffered saline containing $20 \%$ inactivated fetal bovine serum, $2 \%$ Tween 20, and merthiolate, and homogenised by sonication in a Branson sonifier cell disrupter (model B15; Branson Sonic Power Co). The specimens were tested simultaneously by enzyme immunoassay for adenovirus, respiratory syncytial virus, parainfluenza virus types 1 , 2 , and 3 , influenza $A$ and $B$ viruses, and coronavirus OC43. ${ }^{14-18}$

Viral isolation was done as described earlier with some modifications. ${ }^{19}$ Of each specimen, $100 \mu \mathrm{l}$ were inoculated into duplicate roller tube cultures of $\mathrm{HeLa}$ 'Ohio' cells. The cultures were stored in a roller apparatus ( $12 \mathrm{rev} / \mathrm{hour})$ at $33^{\circ} \mathrm{C}$ and examined microscopically every second day. After six days of incubation negative cultures were transferred to fresh medium and incubated for another week. On rare occasions this was done twice. Rhinoviruses were identified by their typical cytopathogenic effect and by lability to acid treatment.

Serum IgG antibodies to adenovirus, influenza $A$, parainfluenza 1,2 , and 3 , coronaviruses OC43 and 229E, and IgG and IgM to Mycoplasma pneumoniae were measured by immunoassay techniques described earlier. $^{15161820}$

\section{ALLERGOLOGICAL STUDIES}

Skin prick tests were done as recommended by the Northern Society for Allergology. ${ }^{21}$ The allergens used were: birch, alder, grass, and mugwort pollen; alternaria and cladosporium moulds; cat and dog dander; and house dust mite (Dermatophagoides pteronyssinus) (Allergologisk Laboratorium, Copenhagen). Reactions of $\geqslant++$ were considered positive. Skin prick tests could not be done on six children because of poor cooperation. Serum samples from these children were tested with radioallergosorbent tests (RAST) with the corresponding antigens. The tests were considered positive when class 2 or greater was obtained. Serum total IgE concentration was measured by Phadebas IgE PRIST (Pharmacia Diagnostics AB). ${ }^{22}$

\section{STATISTICAL ANALYSIS}

The results are shown as mean (SD) unless otherwise stated. The significance of differences between the study and the control groups were calculated by the $\chi^{2}$ test when the distribution in the groups was normal, and otherwise by the Mann-Whitney U test. A probability of $<0.05$ was accepted as significant. In addition, stepwise logistic regression analysis was used to find the best explanatory power associated with wheezing symptoms during the follow up period, and expressed as odds ratios with $95 \%$ confidence intervals. Biomedical Computer Programs (BMDP) statistical software was used for the analyses.

\section{Results}

\section{RETROSPECTIVE ANALYSIS}

Of the 69 controls $15(21 \%)$ had had wheezing attacks sometimes during their lives, six (9\%)

Table 1 Medical histories of patients and control subjects during the year preceding the prospective study. Results are expressed as mean $(S D)$

\begin{tabular}{llll}
\hline Variable & $\begin{array}{l}\text { Patients } \\
(n=54)\end{array}$ & $\begin{array}{l}\text { Controls } \\
\text { subjects } \\
(n=69)\end{array}$ & $\begin{array}{l}p \\
\text { Value }\end{array}$ \\
\hline Episodes of common cold & $7 \cdot 9(3 \cdot 5)$ & $2 \cdot 6(2 \cdot 2)$ & $<0 \cdot 01$ \\
Otitis media & $2 \cdot 5(4 \cdot 4)$ & $0 \cdot 7(1 \cdot 2)$ & $<0 \cdot 01$ \\
Courses of antibiotics & $4 \cdot 0(4 \cdot 5)$ & $1 \cdot 1(1 \cdot 5)$ & $<0 \cdot 01$ \\
Wheezing episodes & $9 \cdot 5(13 \cdot 1)$ & $0 \cdot 2(0 \cdot 8)$ & $<0 \cdot 01$ \\
Admission to hospital for wheezing or dyspnoea & $2 \cdot 3(0 \cdot 3)$ & 0 & Not applicable \\
\hline
\end{tabular}


had had attacks of wheezing during the preceding 12 months, and four (6\%) had visited the hospital outpatient department because of wheezing and dyspnoea. During the year preceding the prospective study, children in the study group had experienced significantly more respiratory infections than their controls (table 1). There were no significant differences, however, when type of day care, number of siblings, or exposure to cigarette smoke were compared (unpublished observations). Patients had had more symptoms suggestive of atopy (table 2).

\section{ALLERGIES AMONG PATIENTS}

Thirty one of the patients in the follow up group $(57 \%)$ had serum total IgE antibodies more than two standard deviations above the mean of normal children in their age group. Skin prick tests (or RAST) were positive in half the children. Thirteen $(24 \%)$ had positive reactions to dog dander, $12(22 \%)$ to cat dander, three $(6 \%)$ to dust mite, and one (2\%) to Cladosporium sp. Positive reactions to some of the other antigens were found in 24 patients (44\%).

To evaluate further the impact of IgE mediated atopy on the susceptibility of these children to respiratory infections and wheezing, a subgroup of highly atopic patients was compared with other children in the study group. The criteria of atopy were those suggested by Carlsen $e t$ $a l .{ }^{23}$ Patients who had both high IgE (2 SD above the mean or more) and positive reactions to skin prick tests (or RAST) were defined as highly atopic in this study. Twenty three patients $(43 \%)$ fulfilled these criteria and were compared with the other 31 patients in the study group. Significant differences were found

Table 2 Incidence of symptoms suggestive of atopy in patients compared with control subjects. Results are expressed as number (\%) of each group

\begin{tabular}{lccc}
\hline Symptom & $\begin{array}{l}\text { Patients } \\
(n=54)\end{array}$ & $\begin{array}{c}\text { Control } \\
\text { subjects } \\
(n=69)\end{array}$ & $p$ Value \\
\hline Atopic eczema & $21(39)$ & $9(13)$ & $<0.01$ \\
Food allergy & $26(48)$ & $14(20)$ & $<0.01$ \\
Reaction to cat or dog & $25(46)$ & $4(6)$ & $<0.01$ \\
Reaction to pollen & $18(33)$ & $6(9)$ & $<0.01$ \\
Reaction to house dust & $16(30)$ & $3(4)$ & $<0.01$ \\
\hline
\end{tabular}

in histories suggestive of inhalation allergy (animals, pollen, or dust) or allergy in general (inhalation or food allergy, or both) but not in the incidence of wheezing attacks (table 3). There were no significant differences in the number of parents who smoked at home or the type of day care of these children.

\section{EPISODES OF RESPIRATORY ILLNESS}

Fifty two (96\%) of all patients had episodes of rhinorrhea or cough, or both, lasting 30 (2) days of the 92 days that followed. In total there were 115 episodes of respiratory symptoms (cough, rhinorrhea, wheezing, or dyspnoea), an average of $2 \cdot 1$ episodes/symptomatic child. Highly atopic children had less episodes than others; $1 \cdot 7$ $(1 \cdot 0)$ compared with $2 \cdot 3(1 \cdot 1)(\mathrm{p}<0.05)$.

In 74 episodes (64\%), the patient was the first person in the family to develop symptoms of the common cold. This occurred significantly more often in children who were cared for in the day care centres $(71 \%)$ or in other families $(73 \%)$ than in those who were cared for at home (45\%) $(\mathrm{p}<0.05)$.

A total of 46 patients (80\%) had episodes of wheezing or dyspnoea during the follow up period. There was no difference in the number of wheezing episodes between highly atopic and other patients (mean 1.3 in both groups). Wheezing started 43 (7) hours (median 23) after the first respiratory symptoms and persisted for $5.0(5 \cdot 5)$ days. In only 11 of the 115 cases $(10 \%)$ did the episode actually start with wheezing.

The duration of wheezing and dyspnoea was 9 (2) days (median 4) during the whole follow up period. To try and explain the occurrence of wheezing for 4 days or less, or longer than 4 days during the follow up period, stepwise regression was used to compare age, sex, medical histories, environmental factors, allergy, results of allergological tests, isolation of viruses, use of prophylactic theophylline or inhalation treatment, and bacterial complications during the episodes. The only explanatory variables found were smoking at home and having more than one sibling (odds ratios 4.8 and 3.0 with $95 \%$ confidence intervals 1.9 to 12.6 and 1.0 to 8.6 , respectively).

During 25 (33\%) of the 76 wheezing episodes

Table 3 Comparison of highly atopic patients (positive skin prick test and IgE concentration more than two standard deviations above the upper limit of the reference range) and other children prone to wheezing. Results are expressed as mean (SD) unless otherwise stated

\begin{tabular}{|c|c|c|c|}
\hline Variable & $\begin{array}{l}\text { Highly atopic } \\
\text { patients } \\
(n=23)\end{array}$ & $\begin{array}{l}\text { Other } \\
\text { patients } \\
(n=31)\end{array}$ & $\overline{p \text { Value }}$ \\
\hline $\begin{array}{l}\text { Age (years) } \\
\text { During life time: }\end{array}$ & $3.9(1.4)$ & $2 \cdot 8(1 \cdot 1)$ & $<0.005$ \\
\hline $\begin{array}{l}\text { No (\%) with symptoms suggestive of allergy } \\
\text { No (\%) with symptoms of inhalation allergy } \\
\text { Wheezing attacks } \\
\text { Treatment with intravenous steroids and theophylline } \\
\text { Admission to intensive care unit } \\
\text { During preceding } 12 \text { months: }\end{array}$ & $\begin{array}{l}22(96) \\
20(87) \\
22 \cdot 1(32 \cdot 8) \\
1 \cdot 0(2 \cdot 1) \\
0\end{array}$ & $\begin{array}{l}15(48) \\
12(38) \\
12 \cdot 8(17 \cdot 9) \\
0 \cdot 7(1 \cdot 3) \\
5(16)\end{array}$ & $\begin{array}{l}<0.001 \\
<0.001 \\
0 \cdot 2 \\
0 \cdot 5 \\
0 \cdot 11^{*}\end{array}$ \\
\hline $\begin{array}{l}\text { Wheezing attacks } \\
\text { Admissions to hospital for dyspnoea } \\
\text { Episodes of common cold } \\
\text { Courses of antibiotics } \\
\text { During follow up: }\end{array}$ & $\begin{array}{l}9 \cdot 6(9 \cdot 6) \\
2 \cdot 8(2 \cdot 3) \\
7 \cdot 4(3 \cdot 3) \\
3 \cdot 1(2 \cdot 7)\end{array}$ & $\begin{array}{l}9 \cdot 5(15 \cdot 3) \\
2 \cdot 0(1 \cdot 6) \\
8 \cdot 3(3 \cdot 7) \\
4 \cdot 7(5 \cdot 5)\end{array}$ & $\begin{array}{l}0 \cdot 9 \\
0 \cdot 04 \\
0 \cdot 4 \\
0 \cdot 2\end{array}$ \\
\hline $\begin{array}{l}\text { Wheezing attacks } \\
\text { No (\%) of admissions to hospital for dyspnoea } \\
\text { No (\%) requiring intravenous treatment of dyspnoea } \\
\text { Episodes of common cold } \\
\text { Diagnosed virus infections } \\
\text { No (\%) requiring course(s) of antibiotics }\end{array}$ & $\begin{array}{l}1 \cdot 3(0 \cdot 8) \\
8(35) \\
2(9) \\
1 \cdot 7(1 \cdot 0) \\
1 \cdot 0(0 \cdot 8) \\
5(22)\end{array}$ & $\begin{array}{l}1 \cdot 3(1 \cdot 1) \\
10(32) \\
3(10) \\
2 \cdot 3(1 \cdot 1) \\
0 \cdot 9(0 \cdot 8) \\
13(42)\end{array}$ & $\begin{array}{c}0.9 \\
0 \cdot 8 \\
0 \cdot 9 \\
<0.05 \\
0 \cdot 7 \\
0 \cdot 1\end{array}$ \\
\hline
\end{tabular}

*Fisher's exact test (two tailed) 
Table 4 Incidence of respiratory infections, wheezing attacks, fever, and admissions to hospital in 54 children prone to wheezing who were followed up for three months

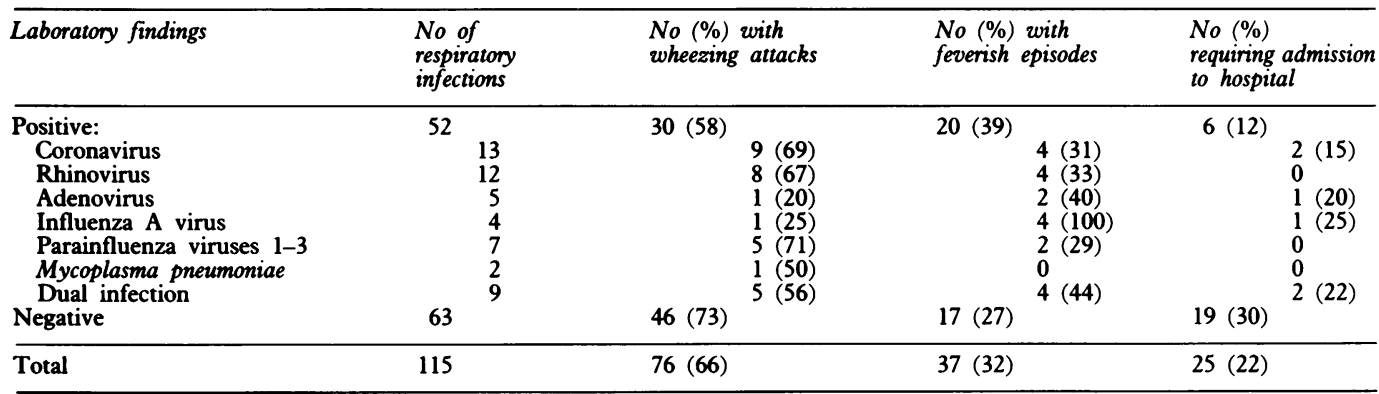

Table 5 Comparison of episodes in which viruses were identified with those in which they were not

\begin{tabular}{|c|c|c|c|}
\hline Variable & $\begin{array}{l}\text { Virus positively } \\
\text { identified } \\
(n=52)\end{array}$ & $\begin{array}{l}\text { Virus not } \\
\text { identified } \\
(n=63)\end{array}$ & p Value \\
\hline $\begin{array}{l}\text { Respiratory symptoms: } \\
\text { Mean (SD) duration } \\
\text { (days) }\end{array}$ & $14 \cdot 8(9 \cdot 1)$ & $14 \cdot 4(9 \cdot 8)$ & 0.8 \\
\hline $\begin{array}{l}\text { Fever: } \\
\text { No (\%) of episodes } \\
\text { Mean (SD) duration } \\
\text { (days) }\end{array}$ & $20(39)$ & $17(27)$ & 0.2 \\
\hline $\begin{array}{l}\text { Wheezing: } \\
\text { No (\%) of episodes } \\
\text { Mean (SD) duration }\end{array}$ & $30(58)$ & $46(73)$ & 0.08 \\
\hline $\begin{array}{l}\text { Admissions to hospital: } \\
\text { No (\%) of episodes } \\
\text { Mean (SD) duration }\end{array}$ & $6(12)$ & $\begin{array}{l}5 \cdot 8(6 \cdot \\
19(30)\end{array}$ & $\begin{array}{l}0.08 \\
0.01\end{array}$ \\
\hline $\begin{array}{l}\text { Mean (SD) duration } \\
\text { (days) }\end{array}$ & $2 \cdot 7(0 \cdot 8)$ & $3 \cdot 8(2 \cdot 1)$ & $<0.001$ \\
\hline $\begin{array}{l}\text { Acute ottis media: } \\
\text { No (\%) of episodes }\end{array}$ & $9(17)$ & $13(21)$ & 0.7 \\
\hline
\end{tabular}

the child was admitted to hospital because of severe dyspnoea. There was no significant difference in the incidence of admissions to hospital between highly atopic and other patients (table 3). When the incidence of admission was further analysed using only the IgE concentrations (age matched) as a basis for subgrouping, no significant differences were found in the rate of admission in patients who had high compared with those who had normal concentrations of serum IgE. Nine (36\%) of the patients who were admitted were treated with intravenous theophylline and corticosteroids because of progressive dyspnoea despite being given oxygen and nebulised salbutamol inhalation in hospital. Seven of these patients had no virus isolated, and one had rhinovirus, and one coronavirus, infection. One patient was treated in the intensive care unit.

Antibiotics were given during 30 of the total of 115 episodes ( $26 \%$ ) ( 22 for otitis media, four for pneumonia, three for tonsillitis, and one for maxillary sinusitis). The rate of admission to hospital (because of dyspnoea) was similar in patients whether or not they had one of these (probable bacterial) infections-seven of 30 compared with 18 of 85 episodes $(23 \%$ and $21 \%$, respectively).

\section{LABORATORY FINDINGS}

Evidence for an infective agent was found in $\mathbf{5 2}$ (45\%) episodes, viruses being implicated in 50 and $M$ pneumoniae in two. The viruses were: coronavirus $(n=22)$, rhinovirus $(n=13)$, parainfluenza viruses $(n=8)$, adenoviruses $(n=8)$, and influenza $A(n=8)$. Nine patients had two types of viruses during their episodes of respiratory symptoms.

Nasopharyngeal specimens were taken during 97 episodes and in 87 of them $(90 \%)$ the specimens were taken within 48 hours after the onset of respiratory symptoms. Coronavirus antigen was found in eight patients, all of whom had pronounced increases in their IgG antibodies in follow up serum samples. Influenza A antigen was detected in two samples and adenovirus antigen in one. Virus isolation yielded 12 rhinoviruses and five adenoviruses. From the eight patients in whom influenza A was diagnosed serology showed the presence of viruses in seven; nasopharyngeal swabs had been taken from four patients, and two of the samples were positive by antigen detection test. From the eight patients in whom adenovirus was detected, six were diagnosed by serology and the virus was isolated from three of them; one of these was also positive by antigen detection assay. Two cases were diagnosed solely on virus isolation. Nasopharyngeal specimens had been taken from all eight of the patients with adenovirus infection. All the eight patients with parainfluenza viruses were diagnosed solely by serology despite the fact that antigen was tested in seven of them. Dual infections were found in nine patients.

All these patients had appreciable increases in coronavirus antibodies, and four had also increased influenzae $\mathrm{A}$, two adenovirus, and one parainfluenzae antibodies. Four had coronavirus antigen in the nasopharyngeal secretion and one had influenza A. Adenovirus was isolated from one patient and rhinovirus from one. Fourfold increases in coronavirus OC43 IgG antibodies were found during 20 episodes, and 229E IgG during two.

SYMPTOMS IN DIFFERENT VIRUS INFECTIONS Episodes of wheezing and fever, and admissions to hospital are shown in table 4. Infections with one or two agents are shown separately. Patients with coronavirus and rhinovirus infections had wheezing attacks lasting $2.4(1.5)$ and $4.3(2 \cdot 3)$ days, and were feverish for $3.0(1.8)$ and 2.5 $(1 \cdot 7)$ days, respectively. Seven of the 37 feverish patients $(19 \%)$ were treated in the hospital because of dyspnoea compared with 18 (33\%) who were not feverish. Eighteen of the 25 patients admitted to hospital (72\%) had no fever. In 15 of the 25 episodes treated in hospital $(60 \%)$ the patients had received prophylactic 
inhalation treatment or theophylline before admission.

When patients from whom viruses had been isolated were compared with those from whom they had not, no significant differences were found in the duration of respiratory symptoms or wheezing (table 5). Patients from whom viruses were not isolated needed significantly more and longer admissions to hospital than those who had a definite virus infection.

\section{Discussion}

Asthmatic children have more respiratory infections than their non-asthmatic siblings. ${ }^{3}$ During the prospective follow up of three months in the present study of younger patients, $94 \%$ of children had rhinorrhea or coughing, or both, on an average of 30 days of the 92 that followed. Laboratory evidence of a viral or mycoplasma infection was found in $45 \%$ of these episodes. The retrospective history of the patients also indicated that they had higher incidence of respiratory infections than their age and sex matched controls. The type of day care of the children did not explain this difference, nor did exposure to cigarette smoke or number of siblings.

An appreciable number of wheezy children are atopic, ${ }^{924} 43 \%$ in this study. The susceptibility to infections was, however, not related to atopy, confirming the report by Isaacs et al. ${ }^{25}$ Recurrent upper and lower respiratory infections and wheezing in children are associated with deficient production of interferon alfa, ${ }^{26}$ and subclasses of IgG antibodies, ${ }^{27}$ which might predispose these children to recurrent infections.

Wheezing occurred in $58 \%$ of the laboratory confirmed viral respiratory infections, and in a third of all wheezing episodes the patients needed treatment in hospital. This is in accordance with previous findings in asthmatic children, among whom from $55 \%$ to $72 \%$ of symptomatic respiratory tract infections resulted in exacerbations of asthma. ${ }^{28-30}$ In a recent analysis of 3358 acute asthmatic attacks seen in an emergency room, $26 \%$ were admitted. ${ }^{31}$

Carlsen et al showed that viruses were the single most common precipitating factor associated with acute asthma in children, ${ }^{23}$ and respiratory viruses were diagnosed in $29 \%$ of episodes of asthma. In the present study the diagnosis of respiratory infection was confirmed in $40 \%$ of wheezing episodes. These two studies differ, however, in that we also studied prospectively those respiratory infections in which the patient did not have wheezing or dyspnoea. In episodes without wheezing viruses were isolated in $56 \%$. This clearly indicates that although viruses are important precipitating factors of wheezy attacks, the outcome of the respiratory infection is variable. The results, although the numbers are small, support the findings of McIntosh et al who found that wheezing is less common when the patient has influenza $A$ than in others, like rhinovirus, coronavirus, or parainfluenza infections. ${ }^{2}$

In addition to the type of virus, the development of wheezing might be dependent on other factors including the severity of the infection. ${ }^{28}$ Horn et al found that the presence of a virus correlated with the severity of the wheezy attack. ${ }^{4}$ In the present study, however, viruses were found in only six (24\%) of those cases admitted to hospital, and the presence of fever did not increase the risk of wheezing in patients with rhinovirus and coronavirus. These different results might be the result of differences in method, because Horn et al found about half of the rhinoviruses only in sputum samples from their patients. This kind of sample could not be collected during this study of younger children.

Although the rate of positive virological diagnosis was high (45\%), underdiagnosis of aetiological factors is obvious. This is especially the case in the high incidence of fever $(27 \%)$ in patients from whom viruses were not isolated. Our effort to isolate viruses was focused on rhinoviruses, and the use of other cell lines might have increased the yield as a number of enteroviruses and herpesviruses do not grow in $\mathrm{HeLa}$ cells as used in this study. Traditionally viruses are thought to play a large part in wheezy bronchitis, and therefore the main goal now was virological diagnosis. Bacterial infections are difficult to diagnose in these patients and it is likely that we also underdiagnosed in this regard. Three $(23 \%)$ of the 13 patients admitted to hospital who were tested had serum $C$. reactive protein concentrations over $40 \mathrm{mg} / \mathrm{l}$, which may suggest the presence of bacterial infection. ${ }^{32}$ Based on recent serological findings, $20-24 \%$ of patients with acute bronchial obstruction have bacterial or mixed viral and bacterial infections. ${ }^{33}$

Although an appreciable number of the patients were atopic, a diagnosed IgE mediated atopy as such did not seem to increase the risk of wheezing further in these children, confirming the work of others. ${ }^{23}$ This result should be interpreted with caution, however, because the highly atopic group was older than the others. It should also be stressed that an appreciable number of children not classified as highly atopic had had some symptoms suggestive for atopy (table 3). By analysis with stepwise regression the most important factors in causing children prone to wheezing to have several wheezing days during the follow up period were smoking at home (as also found by Bisgaard et $a l^{34}$ ) and having more than one sibling. The high ranking of the number of siblings might indicate the importance of infections.

Coronaviruses were the most common respiratory viruses found in this study. The incidence of different viruses is naturally dependent on epidemiological factors. This study was conducted during a period when no respiratory syncytial virus was found in the community. One interesting epidemiological finding was that during the coronavirus outbreak in December 1986 (we also found a high incidence at the same time among army trainees), 22 children (41\%) had the infection. This indicates a high infectivity rate of these viruses in the community. Reinfection with coronaviruses is common, ${ }^{35}$ and in the present study infections occurred even in children who had antibodies to coronaviruses just before the outbreak. In nine laboratory con- 
firmed respiratory infections $(17 \%)$, evidence of more than one virus was found. In all these episodes there was an increase in coronavirus antibodies, but cross reactions between antigens from other viruses are unlikely because no constant combinations between antibody responses to coronavirus or other virsues were found.

The antiasthmatic prophylaxis (theophylline or steroid or sodium cromoglycate inhalations, or a combination) in $39 \%$ of patients might have caused a bias in this study. This is difficult to evaluate because the airway hyper-reactivity in these patients is probably highly variable. It might well be that without prophylaxis some of the patients would have had even more wheezy episodes. Of all the wheezy episodes that required admission to hospital, however, $60 \%$ occurred in patients having continuous prophylaxis, which clearly indicates that the prophylaxic used in this group of young patients was not satisfactory.

In conclusion, this study shows that children who are prone to wheezing have a high morbidity from respiratory infections. Although $43 \%$ of these children were highly atopic the susceptibility to respiratory infections was not associated with diagnosed atopy. Virus infections were diagnosed in $45 \%$ of respiratory episodes but the occurrence of wheezing was not related to the presence of the virus. Wheezing was associated with smoking of the parents at home and having more than one sibling.

We thank Paula Ruusu RN. for assistance, Olli Kaleva for statistical analysis, Kati Hakkarainen for measurement of Mycoplasma tical analysis, Kati Hakkarainen for measurement of Mycoplasma
pneumoniae antibodies, and Dr DAJ Tyrrell of the Medical pneumoniae antibodies, and Dr DAJ Tyrrell of the Medical United Kingdom, for the HeLa 'Ohio' cell cultures.

1 Committee on Infectious Diseases, American Academy of Pediatrics. In: Peter G, ed. Report of the committee on infectious diseases. 12th Ed. Elk Grove Village, Illinois: American Academy of Pediatrics, 1986:479-00.

2 McIntosh K, Ellis EF, Hoffman LS, et al. The association of viral and bacterial respiratory infections with exacerbations of wheezing in young asthmatic children. $\mathcal{F}$ Pediatr 1973;82:578-90.

3 Minor TE, Baker JW, Dick EC, et al. Greater frequency of viral respiratory infections in asthmatic children as compared with their nonasthmatic siblings. $f$ Pediat 1974;85:472-7.

4 Horn MEC, Reed SE, Taylor P. Role of viruses and bacteria in acute wheezy bronchitis in childhood: a study of sputum. Arch Dis Child 1979;54:587-92.

5 Smith JJ, Lemen RJ, Taussig LM. Mechanisms of viralinduced lower airway obstruction. Pediatr Infect Dis $\mathscr{f}$ 1987;6:837-42.

6 Ogra PL. Allergy, respiratory tract infections and bronchial hyperreactivity. Pediatr Infect Dis $\mathcal{F}$ 1989;8:347-52.

$7 \mathrm{Li}$ JTC, O'Connell EJ. Viral infections and asthma. Ann Allergy 1987;59:321-31.

8 Wilson NM. Wheezy bronchitis revisited. Arch Dis Child 1989;64:1194-9.
9 Foucard T, Sjöberg O. A prospective 12-year follow-up study of children with wheezy bronchitis. Acta Paediatr Scand of children with

10 Siegel SC, Rachelefsky GS. Asthma in infants and children: part I. F Allergy Clin Immunol 1985;76:1-14.

11 Skoner D, Caliguiri L. The wheezy infant. Pediatr Clin North Am 1988;35:1011-30.

12 Milner AD. Bronchodilatators in childhood asthma. In: Clark TJ, Cochrane GW, eds. Bronchodilatator therapy: the basis of asthma and chronic obstructive airways disease management. Auckland, New Zealand: ADIS Press, 1984; 93-111.

13 Rachelefsky GS, Siegel SC. Asthma in infants and childrentreatment of childhood asthma: part II. $\mathcal{J}$ Allergy Clin Immunol 1985;76:409-25.

14 Sarkkinen HK, Halonen PE, Arstila PP, Salmi AA. Detection of respiratory syncytial virus, para-influenzae type 2, and adenovirus antigens by radioimmunoassay and enzyme immunoassay on nasopharyngeal specimens from children with acute respiratory disease. $f$ Clin Microbiol with acute respi

15 Meurman O, Ruuskanen O, Sarkkinen H. Immunoassay diagnosis of adenovirus infections in children. $\mathcal{F}$ Clin diagnosis of adenovirus in

16 Meurman O, Sarkkinen H, Ruuskanen O, Hänninen P, Halonen $P$. Diagnosis of respiratory syncytial virus infection in children: comparison of viral antigen detection and serology. F Med Virol 1984;14:61-5.

17 Halonen P, Obert G, Hierholzer JC. Direct detection of viral antigens in respiratory infections by immunoassays: a four year experience and new developments. In: de la Maza $\mathbf{L M}$, Peterson EM, eds. Medical virology IV. New Jersey: Lawrence Erlbaum Associates, 1985:65-83.

18 Koskinen P, Vuorinen T, Meurman O. Influenza A and B virus IgG and IgM serology by enzyme immunoassay. Epidemiol Infect 1987;99:55-64.

19 Arola M, Ziegler T, Ruuskanen O, et al. Rhinovirus in acute otitis media. $f$ Pediatr 1988;113:693-5.

20 Miettinen A, Paavonen J, Jansson E, Leinikki P. Enzyme immunoassay for serum antibody to Mycoplasma hominis in women with acute pelvic inflammatory disease. Sex Transm Dis 1983;10:289-93.

21 Aas K, Belin L. Standardization of diagnostic work in allergy. First report from the standardization committee of the Northern Society of Allergology 1971. Acta Allergology 1972;27:439-68.

22 Kjellman NIM. Predictive value of high IgE levels in children. Acta Paediatr Scand 1976;65:465-71.

23 Carlsen KH, Örstavik I, Leegaard J, Höeg H. Respiratory virus infections and aeroallergens in acute bronchial asthma. Arch Dis Child 1984;59:310-5.

24 Foucard T. The wheezy child. Acta Paediatr Scand 1985;74: 172-8.

25 Isaacs D, Clarke JR, Tyrrell DAJ, Webster ADB, Valman HB. Epidemiology of recurrent respiratory infections in pre-school children. Modern Problems in Paediatrics 1982;21:143-9.

26 Isaacs D, Clarke JR, Tyrrell DAJ, Webster ADB, Valman HB. Deficient production of leucocyte interferon (interferon- $\alpha$ ) in vitro and in vivo in children with recurrent (interferon- $\alpha$ ) in vitro and in vivo in children with recur

27 Lofus BG, Price JF, Lobo-Yeo A, Vergani D. IgG subclass deficiency in asthma. Arch Dis Child 1988;63:1434-7.

28 Minor TE, Dick EC, DeMeo AN, et al. Viruses as precipitants of asthmatic attacks in children. $\mathscr{J} A M A$ 1974;227:292-8.

29 Minor TE, Dick EC, Baker JW, et al. Rhinovirus and influenza type $\mathrm{A}$ infections as precipitants of asthma. $A m$ Rev Respir Dis 1976;113:149-53.

30 Roldaan AC, Masural N. Viral respiratory infections in asthmatic children staying in a mountain resort. Eur $\mathcal{J}$ Respir Dis 1982;63:140-50.

31 Canny GJ, Reisman J, Healy R, et al. Acute asthma: observations regarding the management of a pediatric emergency room. Pediatrics 1989;83:507-12.

32 Putto A, Ruuskanen O, Meurman O, et al. C-reactive protein in the evaluation of febrile illness. Arch Dis Child in the evaluatic

33 Korppi M. Role of infection in respiratory distress in children. Kuopio: University of Kuopio, 1990. (Dissertation.) 34 Bisgaard H, Dalgaard P, Nyboe J. Risk factors for wheezing during infancy. Acta Paediatr Scand 1987;76:719-26.

35 Isaacs D, Flowers D, Clarke JR, et al. Epidemiology of coronavirus respiratory infections. Arch Dis Child 1983;58: $500-3$. 